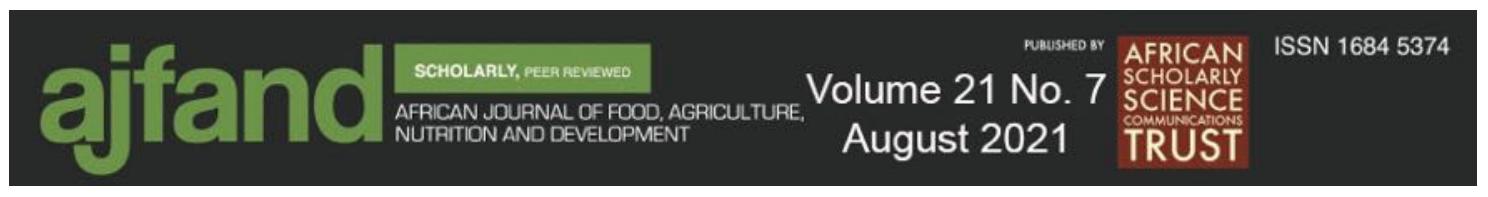

Afr. J. Food Agric. Nutr. Dev. 2021; 21(7): 18330-18348 $\quad$ https://doi.org/10.18697/ajfand.102.20105

\title{
PATTERNS OF RICE PRODUCTION AND YIELDS IN SOUTH EASTERN NIGERIA
}

\section{Mba CL ${ }^{1}$, Madu AI ${ }^{1}$, Ajaero $\mathrm{CK}^{1}$ and AE Obetta ${ }^{2 *}$}

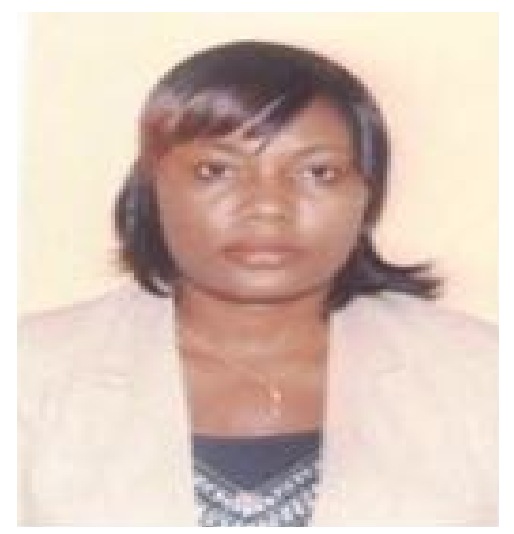

Chinedu Lilian Mba

*Corresponding emails: angela.obetta@unn.edu.ng chinedu.mba@unn.edu.ng

${ }^{1}$ Department of Geography, University of Nigeria, Nsukka, Postal Code 410001, Nsukka, Enugu, Nigeria

${ }^{2}$ Department of Agricultural Economics, University of Nigeria, Nsukka, Postal Code 410001, Nsukka, Enugu, Nigeria 


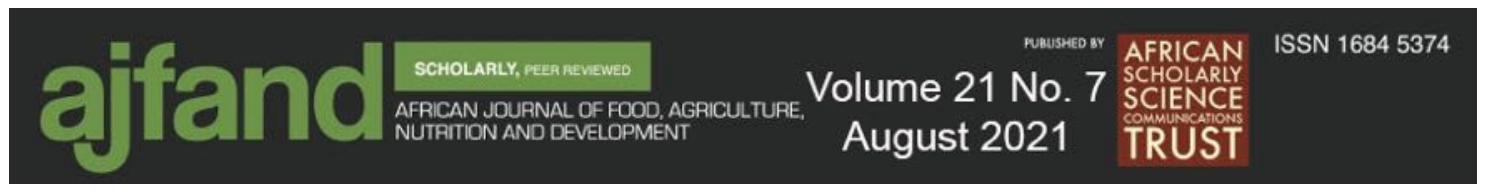

\begin{abstract}
This study assessed the patterns of rice production and yields in South Eastern Nigeria. The study focused on clusters of production systems and estimation of rice yields. The study adopted a questionnaire survey design. The instrument was subjected to face and content validation by three experts and the reliability of the instrument was determined with an internal consistency of 0.79 . Four states, three Local Government Areas (LGAs) from each of the selected states were purposively selected, while two communities were randomly selected from each of the twelve LGAs making a total of twenty four communities. Twenty farm households were randomly selected from each of the two communities making a total of forty farm households per LGA. In all, a total of four hundred and eighty farm households were sampled. Data were collected on the rice types, patterns and yields in South Eastern Nigeria. Data generated were analysed using descriptive statistics, Analysis of Variance (ANOVA) and Pearson correlation with STATA software. The results on the patterns of rice production showed that rainfed dry upland and shallow fadama rice systems were the most widespread rice production systems across the states in the study area. Valley bottoms or 'deep fadama' are practiced in Anambra, Enugu and Ebonyi States. The preferred rice type in Anambra, Enugu and Ebonyi States is MAS 2401, while IR 1416 is the chief variety at Uzo-Uwani LGA of Enugu States and FARO 16 is the most preferred rice type in Abia State. The null hypothesis indicates that there exists a statistically significant variation in the patterns of rice production across the study areas. The mean yield estimation curve identified that Ebonyi State recorded the highest mean estimation production value of $(7,805 \mathrm{~kg} / \mathrm{ha})$ in rice production. The Pearson correlation results indicate that a very high (0.91) relationship exists between rice production patterns and yields in the study area. Based on these findings, it was concluded that the variations in the patterns of rice production across the study had resultant effect on the rice yields. It was recommended that policy makers should address the needs of local rice farmers by providing agricultural interventions at State and Local Government levels through improved agronomic practices, better inputs management and efficient water management to boost production and enable Nigeria attain the Sustainable Development Goals (SDGs) on food security [25].
\end{abstract}

Key words: Rice Production, Spatial Patterns, Rice Yields, Correlation, South eastern Nigeria 


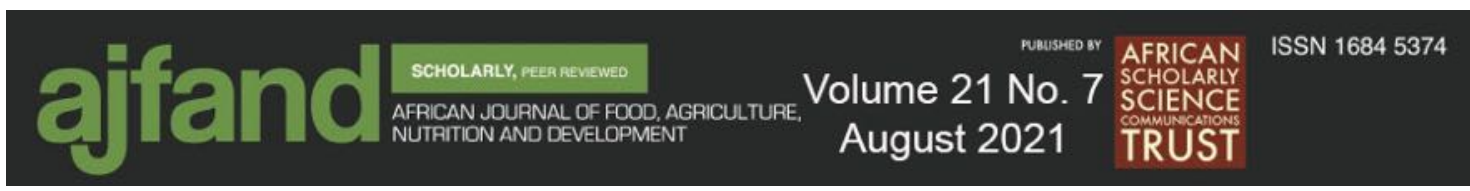

\section{INTRODUCTION}

Rice today is one of the leading staple foods in the world [1]. This fact is due to changing consumer preferences and rapidly increasing population [1]. By virtue of the extent and variety of its uses and adaptability to a broad range of climate, edaphic and cultural conditions, it is a major food crop in the world [2]. The World Bank projected that from 2010, the poorest income class of urban households in Nigeria may obtain not less than 33 percent of their annual cereal-based calories from rice [3]. Among the major cereals, rice is the primary staple of more than hundreds of millions of people in developing economies including Africa [4].

In Africa, Nigeria and Madagascar together produced over $50 \%$ of the rice consumed in sub-Saharan Africa (SSA) in 2004 [5]. The African continent emerged as a major rice importer because rice emerged as the fastest developing food in sub-Saharan Africa in the last decade [6]. As a result, there is considerable increase in demand for rice in Africa than other places round the world [7].

The level of rice consumption in Nigeria has risen greatly (10.3\% and above per year) since the mid-1970s due to increasing population growth rate $(+2.8 \%$ per annum) and rising per capita consumption ( $+7.3 \%$ per annum) and also as a result of shifting consumer preference [8]. Again, rice consumption is accelerating rapidly in the country owing to urbanization, easy cooking, and storage [9]. More so, rice is among the few food crops in Nigeria that is eaten across religious, ethnic, cultural or geographical divides. This food crop is highly prioritized and widely accepted as food during festive periods [10]. Rice is highly revered in many rural areas to the extent that it is prepared mostly on Sundays and local market days [10]. Sustainability is, therefore, paramount in rice production for the nation to fill the gap required for the increasing population.

Rice production flourishes well in humid regions of the sub-tropic and temperate climates and according to Ajijola et al. [11], Nigeria is richly blessed and has the ability to be self-reliant in producing rice because every ecological region throughout the nation can comfortably cultivate rice. Unfortunately, however, the production of this all important food crop is gradually reducing and consequently, the increase in price beyond the reach of many Nigerians [12]. As a result, the country relies hugely on imported rice to the tune of more than five million tonnes per annum, which equates to more than \$ US 800 million [13]. The Federal Government of Nigeria currently banned the land importation of rice to protect smallholder farmers and to encourage selfsufficiency. This policy is stimulating research interest in the local rice production and the state of insufficiency [14], hence, the focus on the study of patterns of local rice production. The inconsistency and the rate of turnover in rice policies over the years has also been high with many policies developed and removed quickly in sequence [15, $16]$.

The current policy on ban of imported rice somewhat encourages domestic production, but other government policies discourage farmers from cultivating rice and pushed some of them to cultivate other crops with similar ecological requirements. Such policies according to Egbedi et al. [17] lack incentives, and have poor market 


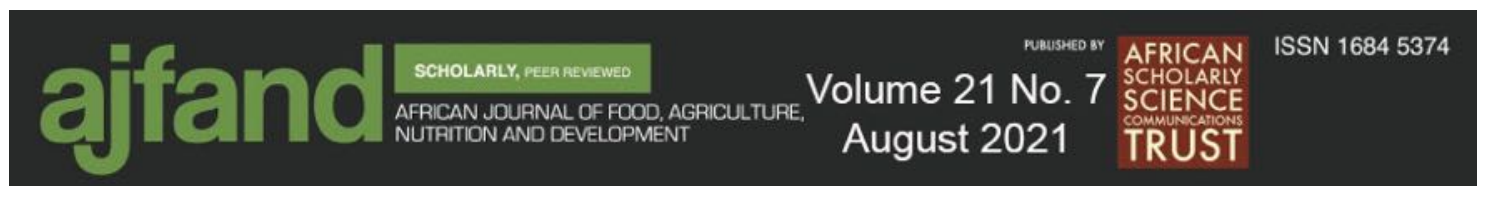

instruction services: absence of coordinated infrastructure, inadequate education and scientifically driven training for farmers to embrace the trending technologies and innovations in the rice sector. Therefore, there is need for detailed assessment of the patterns of rice production in Nigeria, particularly in the south eastern part of the country, which is a major rice producing region.

The country is currently experiencing profound socio-economic and political problems, which have a huge impact on rice production capacity of the country. Some of the problems include unemployment, food insecurity and community/farmers/herdsmen conflicts. According to Bennett [18], various constraining factors in rice production, like physical, biological, socio-economic, and institutional factors, are often improved through research findings and government attention.

Rice production in South Eastern Nigeria is mostly by traditional methods with patches of mechanized methods in some areas [19]. Rice is a major contributor to regional trade in Nigeria. Some farmers are willing to grow rice no matter the constraints they are facing [20]. As rice farmers strive for profitable and sustainable production, researchers and decision makers have to address and respond to issues concerning production patterns and processes.

Studies on rice production abound in Nigeria and beyond. Most of the studies focused mainly on resource productivity and returns, better quality rice type, problems and prospects of rice production and food security among households [10, 21, 22, 23, 24, 25]. Some regional studies in Nigeria focused on the determinants of sustainability of paddy rice production, sustainability and factors influencing sustainability of rice production [26]. An estimation of the variations in rice yields and the factors responsible for them in Northern Ghana was carried out by Tanko et al. [27], using a multivariate regression model to ascertain the parameters of the internal and external factors that influence rice yields. The problems and prospects of rice production in Nigeria were examined by Omofonmwan and Kadiri [28], and their main focus was on farming systems and practices in Edo State. A mix-scale technique (descriptive statistics and Geographic Information System (GIS)) was adopted by Merem et al. [29], to analyse changing trends in rice production in Niger State, Nigeria. The closest so far is a survey in rice production and processing in South Eastern Nigeria by Okeke and Oluka [30], which was an investigative survey approach based on the extent of mechanization applicable in rice production. However, none of these studies provided information on patterns of rice production and yields from farmers' perspectives on a regional scale. As such, no useful comparison can be made at a regional level among the rice producing areas in terms of production patterns and yields for increased production. This constitutes the research gap that this work addressed. The importance of this research, therefore, is to provide better understanding, make informed decisions and recommendations for the achievement of Sustainable Development Goals (SDGs) on food security. In the light of all the above, adequate information about patterns of rice production on a regional scale is a pathway to a sustainable rice development. The study of spatial patterns is in one sense the study of human behavior [31]. Researchers studying patterns attempt to understand why objects are placed in particular locations. For example, this study examines major rice producing communities, rice systems and 


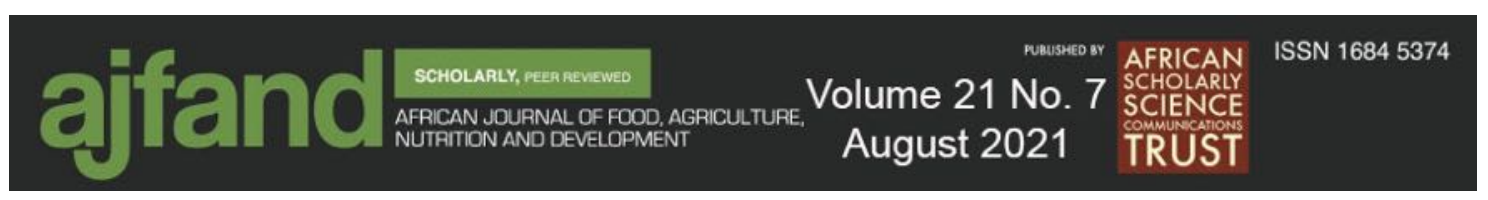

types and rice yields. The main research question is: how do variations in patterns of rice production contribute to rice yields in this area? The null hypothesis is: There is no significant variation in the patterns of rice production across the study area. This research aimed at analysing the spatial patterns of rice production and yields on a regional scale. This was achieved with the following specific objectives: (i) to examine the types of rice production in the area; (ii) to examine the pattern of rice production in the study area; and (iii) to estimate rice yields in the study area. This is necessary because the spatial perspective as discussed above is lacking in previous researches and the policy relevance of this research is for sustainable food security in the country.

\section{MATERIALS AND METHODS}

\section{Study Area}

South Eastern Nigeria comprises of five states namely: Abia, Anambra, Ebonyi, Enugu and Imo. It is one of the six geo-political zones in Nigeria. It is located between latitudes $04^{\circ} 47^{\prime}$ and $07^{\circ} 07^{\prime}$ north of the equator and longitudes $6^{\circ} 35^{\prime}$ and $8^{\circ} 27^{\prime}$ east of the Greenwich meridian. To the north, the study area is bordered by Benue and Kogi States, to the south it is bordered by Rivers State, to the east it is bordered by AkwaIbom and Cross River States and to the west it is bordered by Delta State (Fig.1 and 2)
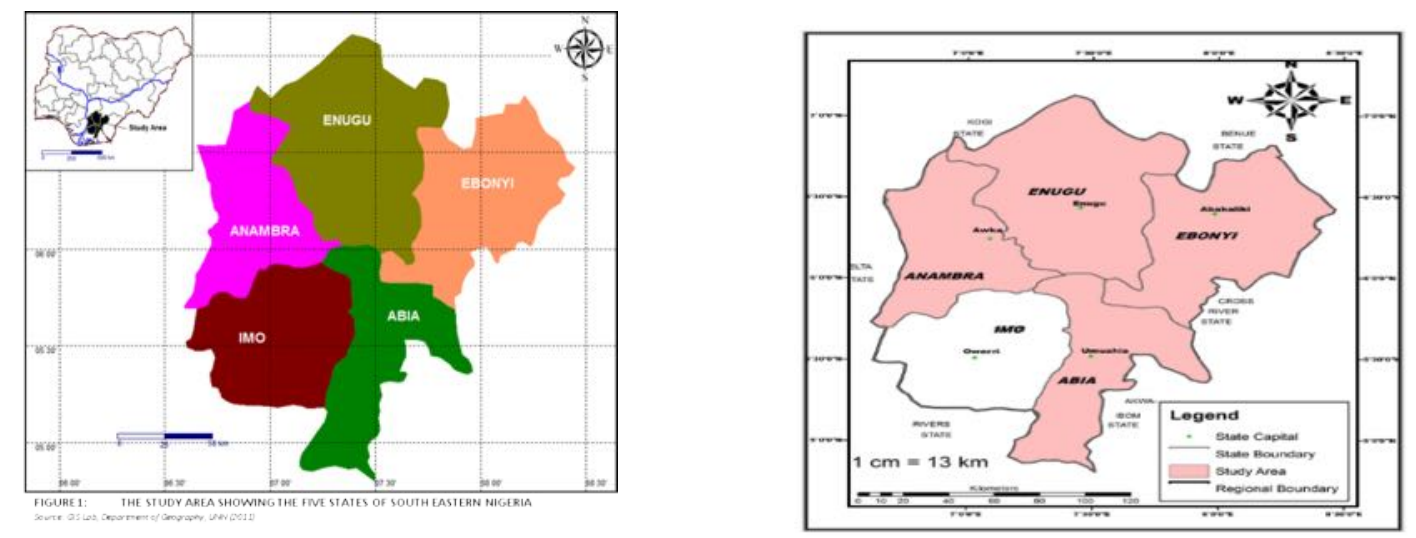

Figure 2: Southeastern Nigeria showing The Study Area (Source: GIS Lab, Department of Geography, UNN) (2017)

The study area is classified into two broad relief regions namely: lowlands, and cuesta landscapes $[32,33]$. The lowlands have heights of less than 400 metres and are made up of the Niger-Anambra lowlands in Anambra State and the undulating lowlands and coastal plains located along the Bende-Ameke-Umuahia axis of Abia State. The cuesta landscapes of more than 350 metres high comprise of the Nsukka-Okigwe cuesta and Awka-Orlu uplands [34].

The study area has a tropical wet-and-dry climate or Aw climate of Koppen's climate classification [35]. Two major vegetation zones are dominant in the study area and they are the rainforest-savannah in the north and the lowland rainforest in the south [36]. The population of the study area according to the 2018 population projection from 2006 population census is $5,480,888,478$ persons [37]. 


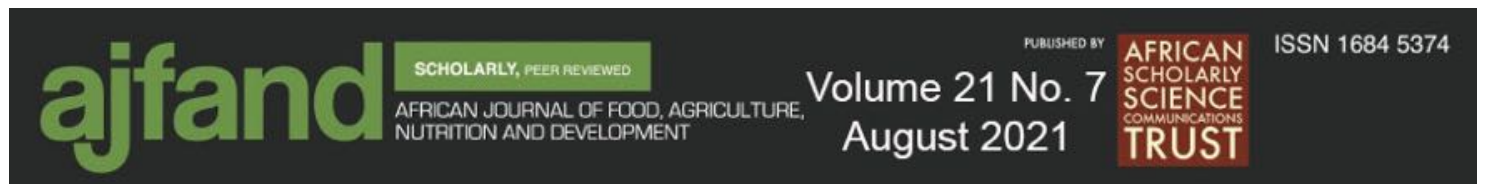

\section{Population and Sample Selection}

All the rice farmers in this zone form the population of the study. A multi-stage sampling technique was used to select the states, Local Government Areas (LGAs), communities and rice farm households. Four out of five States namely: Enugu, Ebonyi, Anambra and Abia States were purposively selected so as to cut across the entire states in the zone and considering the fact that they are predominantly rice growing states. Three LGAs from each of the selected states were purposively selected based on pilot field observations by the researcher, they are the areas where rice is mostly grown within the zone. Two rice producing communities were purposively selected from the three selected LGAs. Also, 20 farm households were randomly selected from each community making a total of 40 farm households per LGA. In all, a total of 480 farm households were sampled. The choice of equal number of respondents selected from the sampled areas was based on convenience and the need to ensure equal representation of respondents from each LGA in the overall study sample.

\section{Data Collection}

The data for this study were collected from primary sources. This was done with the use of questionnaire and observations. A structured questionnaire was used to elicit information on the types and patterns of rice production as well as rice yields in the area. Each questionnaire was administered to rice farm household head within the zone.

\section{Data analysis}

The data collected were analysed using simple descriptive and quantitative statistics such as Means, Percentages and Frequencies. Statistical analysis such as: Analysis of Variance (ANOVA) and Pearson Correlation were also used. The analysis for the hypothesis was done at $0.05 \%$ level of confidence. The Statistics Software Package (STATA 12) was used for the analysis.

Descriptive statistics were used to analyze the types and patterns of rice production across the states of the study area and the percentages derived were shown using tables. Expert Judgement Estimation method was employed to ascertain rice yields in the last farming season (2018). The choice to use the yields of the last farming season was based on the inability of the rice farmers to keep accurate records of their rice yields in the previous years. To determine the average crop yield in $\mathrm{kg} / \mathrm{ha}$, the weight of the sample was multiplied by 1000 following Delphi technique.

Analysis of Variance (ANOVA) was used to test for significant variation in the pattern of rice production across the study area. Pearson correlation was used to ascertain the relationship between the patterns of rice production and rice yields in the study area. 


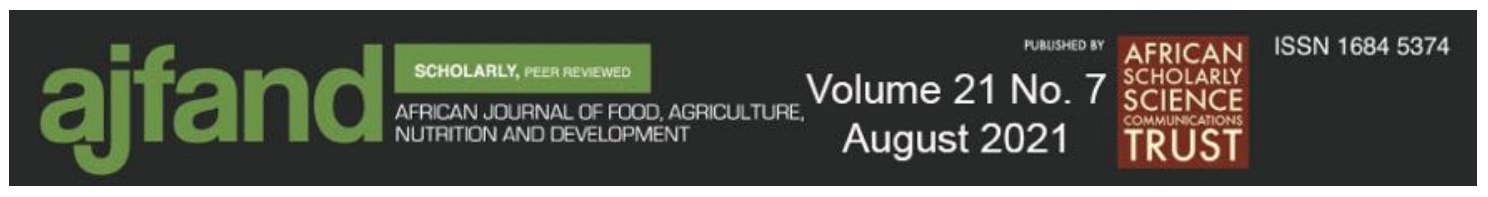

\section{RESULTS AND DISCUSSION}

The results on types and patterns of rice production in southeastern Nigeria shows the percentage variations across the study area.

\section{Preferred Rice Types Grown by Farmers across the States and LGAs in the Study Area}

Table 1 shows the rice types preferred for cultivation by farmers within the LGAs in the study area and the reasons for their choices. Local names were provided for followup research.

The responses from Table 1 showed that MAS and IR 8 are thriving as preferred rice type in all the states of South Eastern Nigeria. IR 1416 is the chief variety at UzoUwani LGA and it is the type that sells first when taken to the market. Federal Agricultural Research Oryza (FARO) 16 is the most preferred rice type in Abia State. International Tropical Agriculture (ITA) 306 and Ex-China (that matures within 90 days) are the chief high yielding types in Ebonyi State. In order to improve on the quality of the rice produce from this region, the de-stoners are strategically positioned at some highly productive points in different states.

\section{Characteristics of Rice Varieties across the states in the Study Area}

The farmers were required to choose the most desirable characteristics in rice (Table 2). The result from Table 2 revealed that high yield (50.2\%) was the most desirable characteristic that farmers required. This was followed by early maturity $(17.9 \%)$, flood tolerance $(13.1 \%)$ and pest and disease resistance $(10.8 \%)$. Other characteristics listed by farmers included: sweet taste, good milling quality, medium duration maturity period, long grain, tall variety, non-lodging, weed resistance and good cooking quality $(7.9 \%)$.

\section{Rice Varieties and Planting Terrain}

The analysis of the types of rice variety grown by the farmers on Table 3 showed that 336 farmers, representing $70 \%$ of the 480 respondents grew improved rice varieties, while 144 farmers, representing 30\% of the sampled farmers grew both local and improved rice varieties. This shows that most of the sampled farmers grow only improved rice varieties.

The information on Table 3 highlights where farmers plant rice. From the table, 103 farmers representing $21.46 \%$ of the entire 480 validly sampled respondents plant their rice on beds. Also, 377 respondents representing 78.54\% of the entire respondents indicated that they plant on flat terrain. This shows that most of the sampled farmers plant on flat terrain.

\section{Systems of Rice Production across the States of Southeastern Nigeria}

Table 4a provides a summary of the dorminant rice production pattern found in each state of the study area. Here, rice production is basically restricted to the rural areas that are far away from the city center. The rice systems identified in the study were grouped under major and minor rice systems. The major rice systems include rain-fed, shallow 


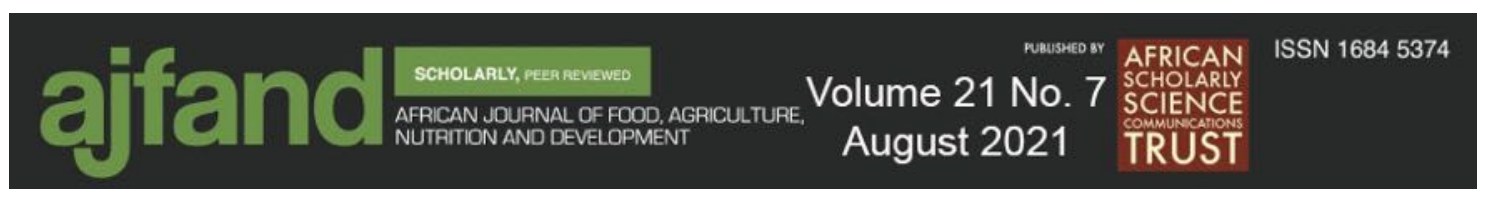

fadama, valley bottoms, while the minor systems were small pumps, hill rice and irrigated rice schemes. Rain-fed field rice, also known as the dry upland system, is widespread.

Results presented in Table 4a showed that greater percentage $(36.7 \%)$ of rice farmers in the study area engage in rain-fed dry upland rice farming. This is followed by those engaged in shallow fadama and valley bottoms with $(28.1 \%$ and $25.2 \%)$, respectively. This indicates that these three systems of rice cultivation are the most widespread of all the rice systems across the study states. They are widespread because the study states all fall under the savannah and rain forest vegetation belts of Nigeria. This is consistent with the report of Oko, Ubi and Efisue [38] that local rice production has been mainly under upland conditions and primitive agronomic practices, with farmers clearing new forest lands every year.

The waterlogged shallow fadama rice field system is also common because it is practiced along the major drainage systems, minor watercourses and tributaries. Valley bottoms or 'deep fadama' also provide the ideal environment for rice production.

However, due to lack of flood control technology and appropriate varieties, this system remains largely untapped. Irrigated rice schemes were started in almost all the states in the savannah zone and owned by government agencies like the River Basin Development Authority (RBDA), Anambra/Imo River Basin Development Authority, Adani rice scheme and the Abakaliki irrigation scheme. However, most of them are not in use presently due to underfunding and a complete breakdown in infrastructural facilities. Some schemes like RBDAs in Anambra and a section in Abia are back onboard now but they are relying on potable water supply projects at the moment. Therefore, the rice schemes will still not be very vibrant for a couple of years in this region.

Results from Table $4 \mathrm{~b}$ show that rice farmers that engage in rain-fed dry upland rice farming cultivated higher percentage $(45.8 \%)$ of local and improved rice variety than only the improved rice variety $(32.7 \%)$. In any case, rice farmers that engaged in shallow fadama $(28.9 \%)$ cultivated more rice than those of valley bottom rice systems $(27.7 \%)$ and of improved rice variety $(26.4 \%)$ than local and improved rice varieties $(19.5 \%)$.

This indicates that among the three most widespread rice production systems across the study area, $36.7 \%$ of rice farmers engaged in rain-fed dry upland rice system cultivated both local and improved rice varieties while $28.1 \%$ and $25.2 \%$ of rice farmers engaged in shallow fadama and valley bottom rice system cultivated both local and improved farming system, respectively.

This further indicates that both local and improved rice varieties are widely cultivated across major rice systems in South Eastern Nigeria. According to Adenuga et al. [39], rice farmers choose rice varieties with high yielding capacity, adapted to the region's length of growing season, soil, altitude and for paddy farmers, the depth of water in the fields. Improved rice varieties $O$. sativa (Oryza sativa) which are all listed in Table 1, since the 1960s had taken over from the local rice O. glaberrima, (Oryza glaberrim 


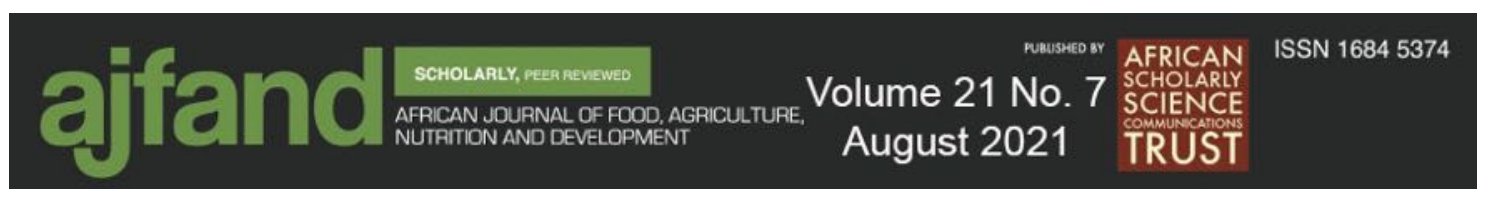

Steud), which is now limited to some deep-flooded plains of river basins and other isolated pockets of deep swamps all over the study area.

\section{Testing of Null Hypothesis: There is no Significance Difference in the Patterns of Rice Production across the Study Area}

The result in Table 5 is the test for the significant difference in the patterns of rice production across South Eastern Nigeria. The null hypothesis states there is no statistical significant difference in the patterns of rice production across the study areas. The result showed that the between group difference was 63.97, while the within group difference was 205.18. This showed that the difference was more within the groups. The result here depicts that the difference in patterns of rice production was more inside (within) the states than between the states. However, the probability value of 0.00 for the differences in rice production across the states was lower than the maximum probability value for significance of 0.05 , depicting that though the within group differences was higher than between group difference, the difference was significant. Based on this, the study rejected the null hypothesis and concludes that there exists a statistically significant difference in the patterns of rice production across the study areas.

In order to ascertain where the significant difference emanated from, the study employed the Scheffe Post Hoc ANOVA analysis. The result from Table 6 showed that the significant difference came from the mean of Anambra and Enugu State, Anambra and Ebonyi State, Abia and Enugu State and Abia and Ebonyi State.

Average Rice Yields for the Last Farming Season (2018) across States of the Study Area

Table 7 shows the average rice yields across the states in the last farming season. The normal average rice yield curve is shown in Figure 3.

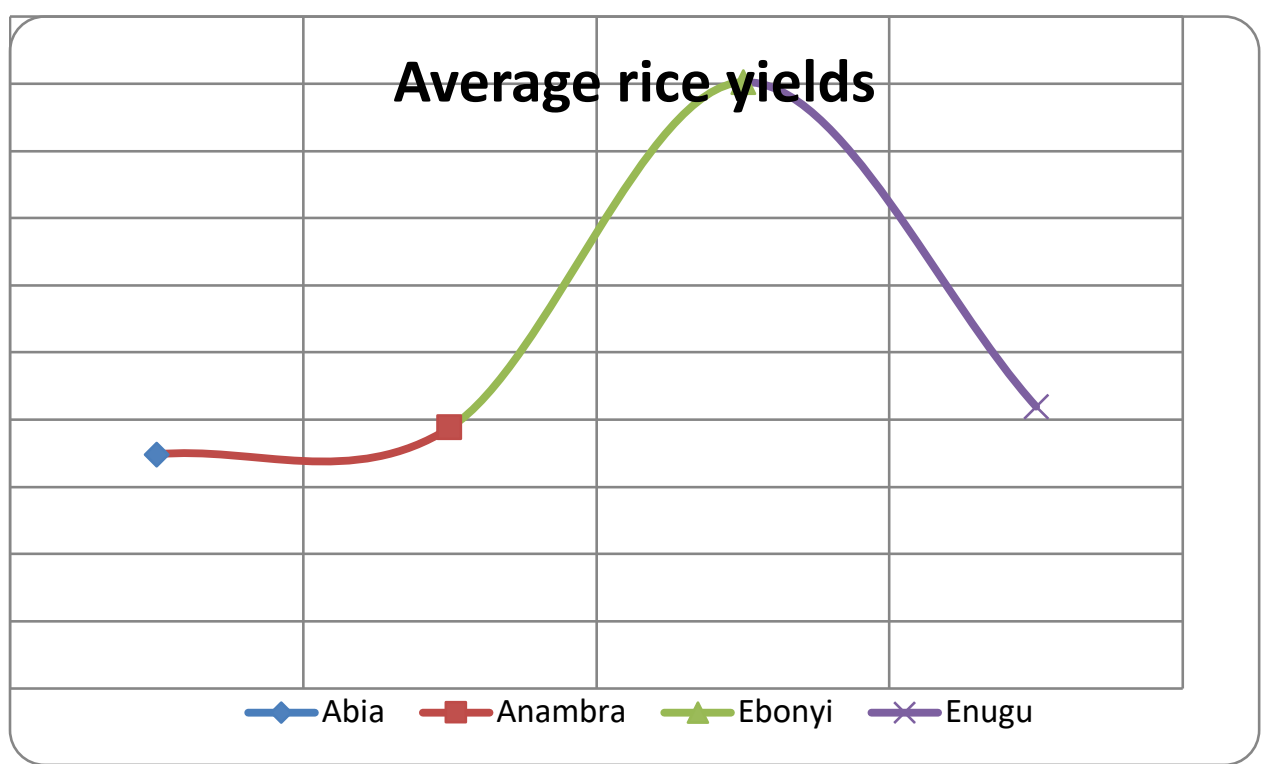

Figure 3: Average Rice Yields by State 


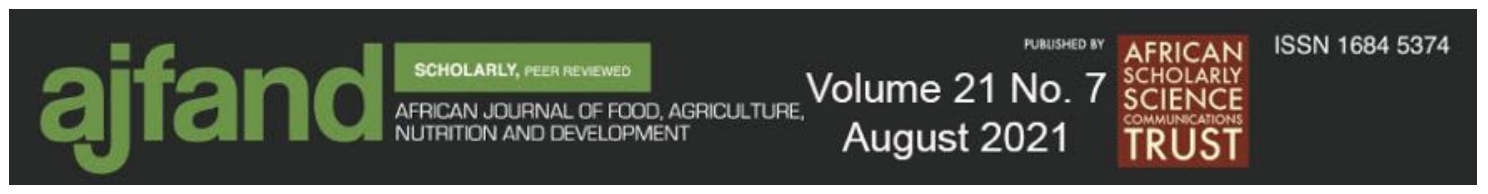

The findings from the normal average rice yield curve reveal that the sampled states combined had a mean estimated rice yield of $28,117 \mathrm{~kg} /$ ha in the last farming season (2018). Across the sampled states, given the same input per hectare, Enugu, Anambra and Abia States recorded a lower mean estimation rice yield of $6,776 \mathrm{~kg} / \mathrm{ha}$ and $6,697 \mathrm{~kg} / \mathrm{ha}$, respectively, while Ebonyi State recorded a higher mean estimation rice yield of $7,805 \mathrm{~kg} / \mathrm{ha}$. This was not expected especially in Anambra State because, Anambra State has the absolute advantage to produce more due to the natural endowments (large expanse of flood plain/prone areas, good number of drainage systems, among others). Anambra and Ebonyi States enjoy these natural endowments more than other states.

To classify the region according to their level of production, the result of the rice yields was used to map spatial variability in rice yields across the states. This was done by classifying the region into four classes namely: very high, high, moderate and low using the mean value of the yields. The spatial map was shown in Figure 4.

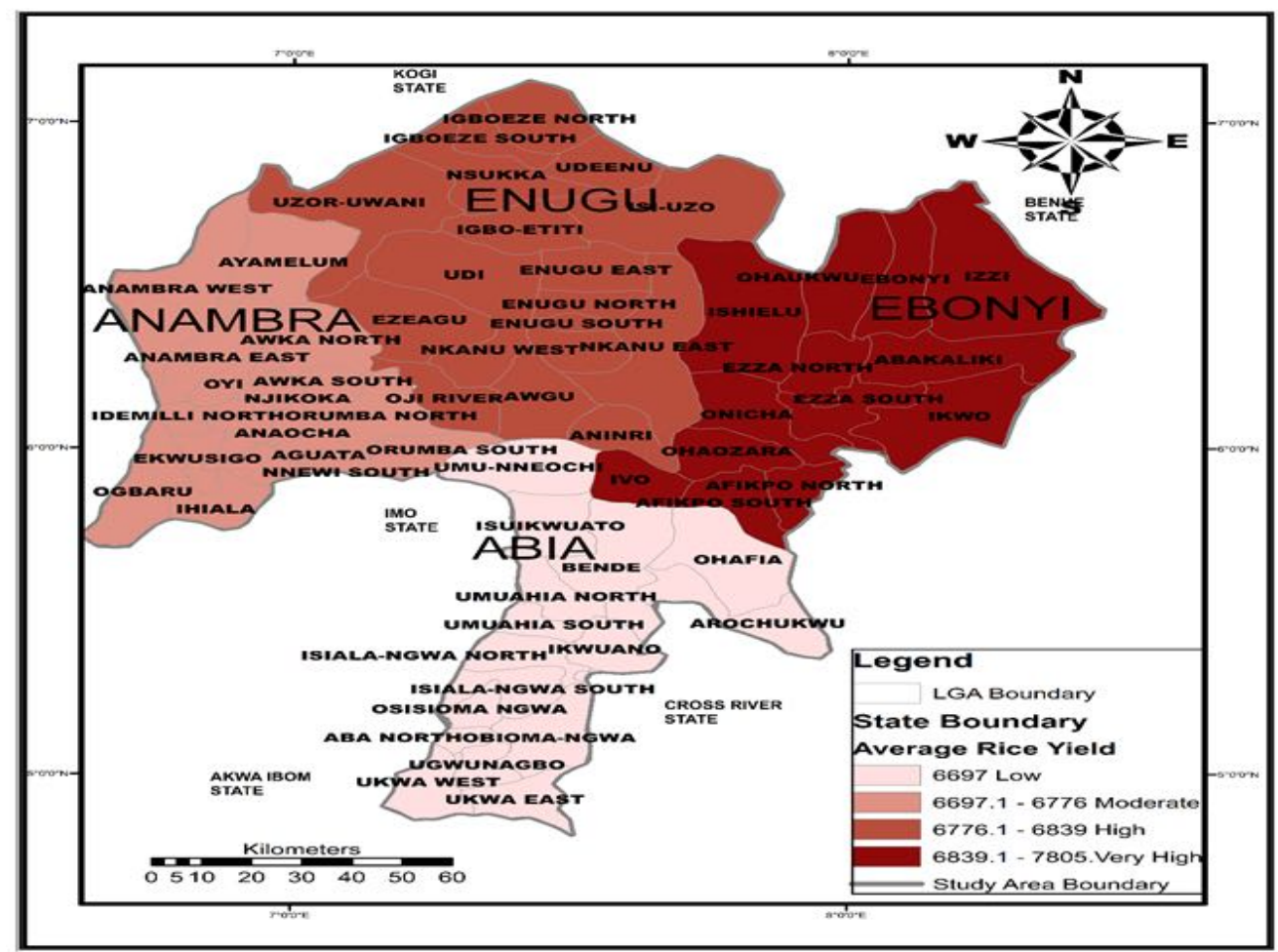

Figure 4: Average rice yields by States

Figure 4 presents a general picture of the spatial differentiation in average rice yields in South Eastern Nigeria. From this spatial map, Ebonyi and Enugu States recorded high rice yield with Ebonyi State taking the lead because of very high extent of harvest. Meanwhile, Anambra and Abia States recorded moderate and low yields, respectively due to a lower extent of harvest. This differentiation in rice yields across the states can be attributed to variations in the patterns of rice production in the study states. 


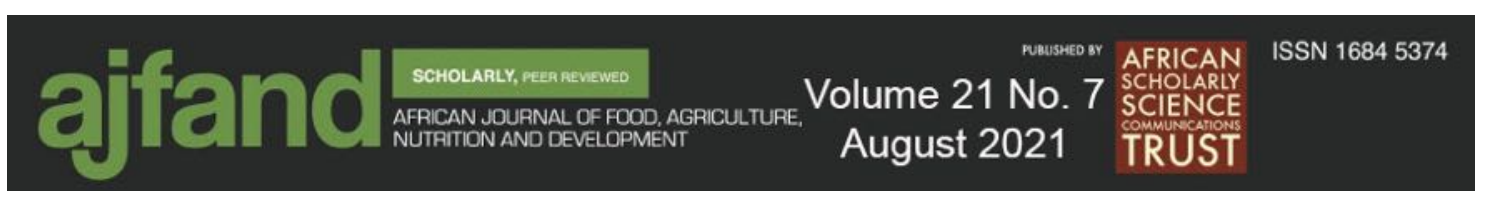

The result from Table 8 showed that the relationship between production patterns and quantity of rice produced of 0.91 was very high. This depicts a very strong relationship. It also implies that as production patterns improve, quantity of rice produced increases. This is in line with the deduction from Ndebeh et al. [37] that improved rice varieties contribute to larger rice production.

\section{CONCLUSION}

This study covered the patterns of rice production and yields in South Eastern Nigeria. It was concluded that there exists a statistically significant variation in the patterns of rice production across the study area. Ebonyi State had the highest rice yield of $7,805 \mathrm{~kg} / \mathrm{ha}$ which was partly due to high government interests in providing the necessary inputs, equipment and technology to the reach of rice farmers. This level of government interests should be activated and replicated in other states for increased rice yields across the region. This assertion is necessary because, Anambra State has the same absolute advantage with Ebonyi State to produce more due to their natural endowments (large expanse of flood plain/prone areas, good number of drainage systems, among others). From the findings, $70 \%$ of the respondents cultivated only improved rice variety. This is attributed to the preferred characteristics of the improved rice varieties. However, the improved rice varieties should not replace the existing indigenous ones since majority of the indigenous varieties have got several advantages over some improved varieties especially in most of the agronomic traits. However, the resulting revelations from the spatial perspective of rice growing areas showed the states that need more government interventions in order to boost their yield capacity. The policy makers should pay attention to the needs of individual states by investing more in agricultural interventions at States and Local Government levels so as to boost production, that will enable Nigeria attain the Sustainable Development Goals (SDGs) for food security. 


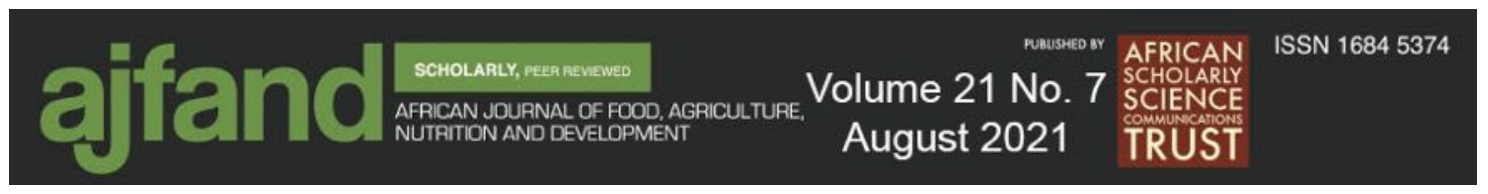

Table 1: Preferred Rice Types Grown by Farmers across the States and LGAs in the Study Area

\begin{tabular}{|c|c|c|c|c|}
\hline State & LGAs & Prefered variety & Reasons for choice & $\begin{array}{l}\text { Location for } \\
\text { de-stoners }\end{array}$ \\
\hline \multirow[t]{3}{*}{ Anambra } & Ayamelum & MAS, IR 8, IR 5 & $\begin{array}{l}\text { High yield, Sweet, } \\
\text { long grains }\end{array}$ & \multirow[t]{3}{*}{ Omo, } \\
\hline & $\begin{array}{l}\text { Orumba } \\
\text { North }\end{array}$ & MAS, FARO 16 & $\begin{array}{l}\text { High yield, Sweet, } \\
\text { long grains }\end{array}$ & \\
\hline & Ogbaru & IR 8, IR 5, MAS & High yield, Taste & \\
\hline \multirow[t]{3}{*}{ Enugu } & Uzo-Uwani & $\begin{array}{l}\text { IR 1416, MAS, IR 5, IR 8, } \\
\text { SMA }\end{array}$ & $\begin{array}{l}\text { High yield, Sweet, } \\
\text { long shelf life, sells } \\
\text { better than imported } \\
\text { rice }\end{array}$ & \multirow[t]{3}{*}{$\begin{array}{l}\text { Adani, } \\
\text { Ugboka }\end{array}$} \\
\hline & Isi-Uzo & $\begin{array}{l}\text { MAS, IR 5,IR 8, FARO 16, } \\
\text { Danpate (similar to IR 1416) }\end{array}$ & $\begin{array}{l}\text { High yield, Good } \\
\text { taste }\end{array}$ & \\
\hline & Awgu & MAS, IR 8, IR 5, SMA & $\begin{array}{l}\text { High yield, Good } \\
\text { taste, good looking }\end{array}$ & \\
\hline \multirow[t]{3}{*}{ Abia } & Bende & FARO 15 MAS, IR 8 & $\begin{array}{l}\text { High yield, Sweet, } \\
\text { long grain }\end{array}$ & \multirow[t]{3}{*}{$\begin{array}{l}\text { Abam, } \\
\text { Uzoakoli }\end{array}$} \\
\hline & Isikwuato & FARO 16, IR 8, IR 5, MAS & $\begin{array}{l}\text { High yield, Sweet } \\
\text { taste }\end{array}$ & \\
\hline & Arochukwu & FARO 16 IR 5, MAS & $\begin{array}{l}\text { High yield, Sweet, } \\
\text { good looking }\end{array}$ & \\
\hline \multirow[t]{3}{*}{ Ebonyi } & Izzi & $\begin{array}{l}\text { MAS, IR 5, IR 8, ITA 306, EX- } \\
\text { China (90 days maturity period) }\end{array}$ & High yield, Sweet & \multirow[t]{3}{*}{$\begin{array}{l}\text { Abakaliki } \\
\text { and Ikwo }\end{array}$} \\
\hline & Ezza & $\begin{array}{l}\text { MAS, IR 5, IR 8, ITA 306, EX- } \\
\text { China (90 days maturity period) }\end{array}$ & $\begin{array}{l}\text { High yield, Sweet, } \\
\text { grains do not stick }\end{array}$ & \\
\hline & Ikwo & $\begin{array}{l}\text { MAS, IR 5, IR 8, ITA } 306, \text { EX- } \\
\text { China ( } 90 \text { days maturity period) }\end{array}$ & $\begin{array}{l}\text { High yield, Good } \\
\text { taste, good looking }\end{array}$ & \\
\hline
\end{tabular}

Table 2: Distribution of Rice Farmers by Desired Characteristics for Rice across the States in the Study Area

\begin{tabular}{|l|l|l|l|l|l|l|}
\hline State & High yield & $\begin{array}{l}\text { Early } \\
\text { maturity }\end{array}$ & $\begin{array}{l}\text { Flood } \\
\text { tolerant }\end{array}$ & $\begin{array}{l}\text { Pests/Diseases } \\
\text { resistant }\end{array}$ & $\begin{array}{l}\text { Others (long } \\
\text { grain, sweet } \\
\text { taste, etc) }\end{array}$ & Total \\
\hline Anambra & $59(49.2 \%)$ & $21(17.5 \%)$ & $19(15.8 \%)$ & $13(10.8 \%)$ & $8(6.6 \%)$ & $120(100 \%)$ \\
\hline Enugu & $62(51.7 \%)$ & $24(20.0 \%)$ & $5(4.2 \%)$ & $16(13.3 \%)$ & $13(10.8 \%)$ & $120(100 \%)$ \\
\hline Abia & $55(45.8 \%)$ & $26(21.7 \%)$ & $16(13.3 \%)$ & $12(10.0 \%)$ & $11(9.2 \%)$ & $120(100 \%)$ \\
\hline Ebonyi & $65(54.2 \%)$ & $15(12.5 \%)$ & $23(19.2 \%)$ & $11(9.2 \%)$ & $6(5.0 \%)$ & $120(100 \%)$ \\
\hline Total & $241(50.2 \%)$ & $86(17.9 \%)$ & $63(13.1 \%)$ & $52(10.8 \%)$ & $38(7.9 \%)$ & $480(100 \%)$ \\
\hline
\end{tabular}




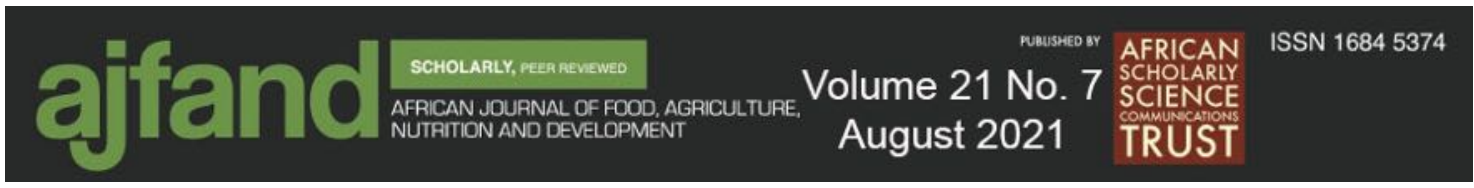

Table 3: Distribution of rice farmers by Types of Rice Varieties Grown and Planting Terrains

\begin{tabular}{lll}
\hline Items Raised & Frequency & Percentage \\
\hline Type of rice varieties grown & & \\
Improved rice variety & 336 & 70.0 \\
Local and improved rice variety & 144 & 30.0 \\
Total & 480 & 100.0 \\
& & \\
\hline Planting Terrains & & \\
Beds & 103 & 21.46 \\
Flat terrain & 377 & 78.54 \\
Total & 480 & 100.0 \\
\hline
\end{tabular}

Table 4a: Rice Production Systems Across the Selected States

\begin{tabular}{|c|c|c|c|c|c|c|c|}
\hline & \multicolumn{3}{|c|}{ Major rice systems } & \multicolumn{3}{|c|}{ Minor rice systems } & \\
\hline States & $\begin{array}{l}\text { Rain-fed dry } \\
\text { upland }\end{array}$ & $\begin{array}{l}\text { Shallow } \\
\text { fadama }\end{array}$ & $\begin{array}{l}\text { Valley } \\
\text { bottoms }\end{array}$ & $\begin{array}{l}\text { Small } \\
\text { pumps }\end{array}$ & Hill rice & $\begin{array}{l}\text { Irrigated } \\
\text { rice } \\
\text { Scheme }\end{array}$ & Total \\
\hline Anambra & $22(18.3 \%)$ & $35(29.5 \%)$ & $51(42.5 \%)$ & $8(6.6 \%)$ & $4(3.3 \%)$ & $0(0.0)$ & $120(100 \%)$ \\
\hline Enugu & $52(43.3 \%)$ & $18(15.0 \%)$ & $38(31.6 \%)$ & $9(7.5 \%)$ & $3(2.5 \%)$ & $0(0.0)$ & $120(100 \%)$ \\
\hline Abia & $55(45.8 \%)$ & $49(40.8 \%)$ & $9(7.5 \%)$ & $3(2.5 \%)$ & $4(3.3 \%)$ & $0(0.0)$ & $120(100 \%)$ \\
\hline Ebonyi & $47(39.1 \%)$ & $33(27.5 \%)$ & $23(19.1 \%)$ & $15(12.5 \%)$ & $2(1.6 \%)$ & $0(0.0)$ & $120(100 \%)$ \\
\hline Total & $176(36.7 \%)$ & $135(28.1 \%)$ & $121(25.2 \%)$ & $35(7.3 \%)$ & $13(2.7 \%)$ & $0(0.0)$ & $480(100 \%)$ \\
\hline
\end{tabular}

Table 4b: Farming Systems by Rivers Varieties Cultivated

\begin{tabular}{|l|l|l|l|l|l|l|l|}
\hline & \multicolumn{3}{|l|}{ Major rice systems } & \multicolumn{2}{l|}{ Minor rice systems } & \\
\hline $\begin{array}{l}\text { Rice } \\
\text { Varieties } \\
\text { cultivated }\end{array}$ & $\begin{array}{l}\text { Rain-fed } \\
\text { dry upland }\end{array}$ & $\begin{array}{l}\text { Shallow } \\
\text { fadama } \\
\text { Valley } \\
\text { bottoms } \\
\text { variety }\end{array}$ & $\begin{array}{l}\text { Small } \\
\text { pumps }\end{array}$ & Hill rice & $\begin{array}{l}\text { Irrigated } \\
\text { rice } \\
\text { Scheme }\end{array}$ & Total \\
\hline $\begin{array}{l}\text { Local and } \\
\text { improved } \\
\text { varieties }\end{array}$ & $66(45.8 \%)$ & $38(26.4 \%)$ & $28(19.5 \%)$ & $11(7.6 \%)$ & $1(0.7 \%)$ & $0(0.0)$ & $\mathbf{1 4 4 ( 1 0 0 \% )}$ \\
\hline Total & $\mathbf{1 7 6 ( 3 6 . 7 \% )}$ & $\mathbf{1 3 5 ( 2 8 . 1 \% )}$ & $\mathbf{1 2 1 ( 2 5 . 2 \% )}$ & $\mathbf{3 5 ( 7 . 3 \% )}$ & $\mathbf{1 3 ( 2 . 7 \% )}$ & $\mathbf{0 ( 0 . 0 )}$ & $\mathbf{4 8 0 ( 1 0 0 \% )}$ \\
\hline
\end{tabular}




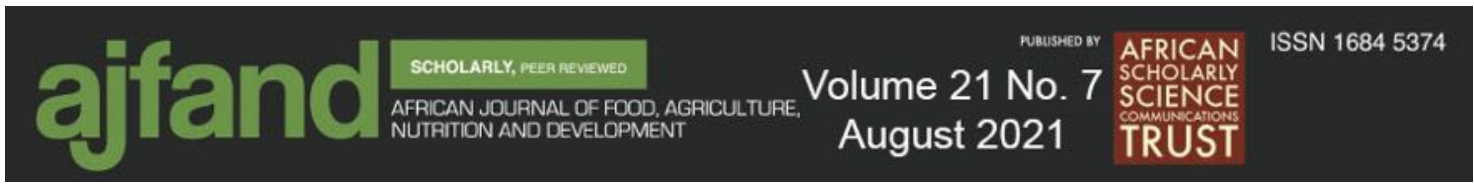

Table 5: ANOVA for Significant Difference on Pattern of Rice Production across the Study Area: Testing of Hypothesis One

\begin{tabular}{lccc}
\hline Source & Sum of Square & Df & P Value \\
\hline Between groups & 63.97 & 3 & 0.00 \\
Within groups & 205.18 & 475 & \\
\hline
\end{tabular}

Source: Researchers Field Survey, 2018

Table 6: Scheffe Multiple ANOVA Comparison Test for Hypothesis One

\begin{tabular}{|ll|r|r|r|r|r|}
\hline (I) Group2 & (J) Group2 & $\begin{array}{r}\text { Mean Difference } \\
(\mathrm{I}-\mathrm{J})\end{array}$ & Std. Error & Sig. & \multicolumn{2}{|c|}{$95 \%$ Confidence Interval } \\
\cline { 5 - 7 } & & .03565 & .17145 & .998 & -.4482 & .5195 \\
Anambra & Abia State & $.78957^{*}$ & .17145 & .000 & .3057 & 1.2734 \\
State & Enugu State & $.76065^{*}$ & .17145 & .000 & .2768 & 1.2445 \\
& Ebonyi State & -.03565 & .17145 & .998 & -.5195 & .4482 \\
& Anambra State & $.75391^{*}$ & .17145 & .000 & .2701 & 1.2378 \\
Abia State & Enugu State & $.72500^{*}$ & .17145 & .001 & .2411 & 1.2089 \\
& Ebonyi State & $-.78957^{*}$ & .17145 & .000 & -1.2734 & -.3057 \\
& Anambra State & $-.75391^{*}$ & .17145 & .000 & -1.2378 & -.2701 \\
Enugu State & Abia State & -.02891 & .17145 & .999 & -.5128 & .4549 \\
& Ebonyi state & $-.76065^{*}$ & .17145 & .000 & -1.2445 & -.2768 \\
& Anambra State & $-.72500^{*}$ & .17145 & .001 & -1.2089 & -.2411 \\
\multirow{2}{*}{ Ebonyi State } & Abia State & .02891 & .17145 & .999 & -.4549 & .5128 \\
& Enugu State & &
\end{tabular}

*. The mean difference is significant at the 0.05 level

Table 7: Average Rice yields by States

\begin{tabular}{|l|l|l|l|l|l|}
\hline States & Anambra & Enugu & Ebonyi & Abia & Total \\
\hline Average rice yields (Kg/Ha) & 6,776 & 6,839 & 7,805 & 6,697 & 28,117 \\
\hline
\end{tabular}

Source: Author's computation (2018) 


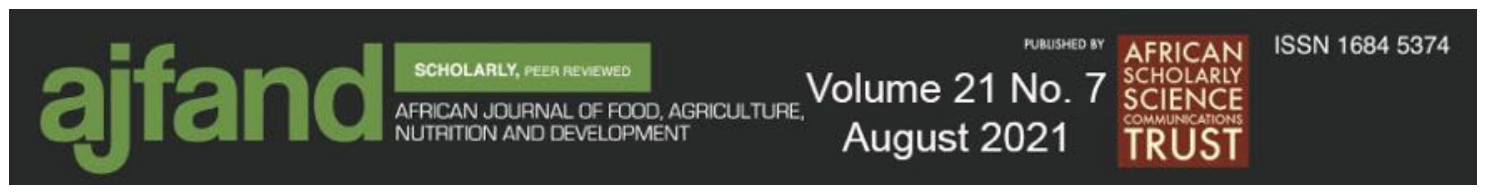

Table 8: Correlation between Production Patterns and Quantity of Rice Produced in the Study Area

\begin{tabular}{|ll|l|l|}
\hline & $\begin{array}{l}\text { Production } \\
\text { Patterns }\end{array}$ & Qty of rice produced \\
\hline Productpatterns & Pearson Correlation & 1 & -.005 \\
& Sig. (2-tailed) & & .906 \\
& $\mathrm{~N}$ & 480 & 480 \\
& Pearson Correlation & -.005 & 1 \\
Qtyriceproduced & Sig. (2-tailed) & .906 & \\
& $\mathrm{~N}$ & 480 & 480 \\
\hline
\end{tabular}




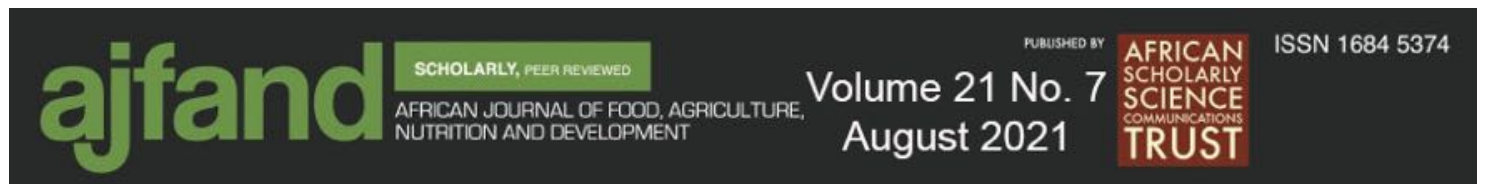

\section{REFERENCES}

1. Muthaya S, Sugimoto JD, Montgomery S and GF Maberly An overview of global rice production, supply, trade and consumption. Annals of the New York Academy of Sciences. 2014; Issue 1324: 7-14.

2. Federal Ministry of Agriculture and Rural Development (FMARD). Commercial Feasibility Study Report for the Establishment of Rice Processing Mills in Nigeria. Accenture, Nigeria. 2012: 79.

3. United States Department of Agriculture (USDA). World rice prices more volatile after '08 spike. Delta Farm Press. 2014; 71(3):15.

4. National Agricultural Extension and Research and Liaison Service (NAERLS). Agricultural Performance Survey, Kano State. 2010.

5. Onyango AO Exploring options for improving rice production to reduce hunger and poverty in Kenya. World environment. 2014; 4(4): 172-179.

https://doi.org/10.5923/j.env.20140404.03

6. Akande $\mathbf{T}$, Cisse $\mathbf{Y}$ and $\mathbf{P}$ Kormawa Streamlining policies for enhancing rice production in Africa: past experiences, lessons learnt and the way forward. African crop science journal. 2015; 15(4): 223 - 235.

7. Nasrin S, Lodin JB, Jirström M, Holmquist B, Djurfeldt AA and G Djurfeldt Drivers of rice production: evidence from five Sub-Saharan African countries. Agriculture \& Food Security. 2015; 4:12. https://doi.org/10.1186/s40066-015$\underline{0032-6}$

8. Idris A, Rasaki K, Hodefe OJ and B Hakeem Consumption pattern of ofada rice among civil servants in Abeokuta metropolis of Ogun State, Nigeria. Journal of biology, agriculture and healthcare. 2013; 3(6):106-112.

9. Uga Y, Sugimoto K, Ogawa $\mathbf{S}$, Rane $\mathbf{J}$ and $\mathbf{M}$ Ishitani Control of root system architecture by DEEPER ROOTING 1 increases rice yield under drought conditions. Nat Genet. 2013; 45: 1097-1102.

10. Basorun JO Expository analysis of rice processing activities in Igbemo, rural Nigeria. American journal of social issues and humanities. 2013; 3(2): 79-81.

11. Ajijola S, Usman JM, Egbetokun OA, Akoun J and CS Osalusi Appraisal of rice production in Nigeria: A case study of north central states of Nigeria. Journal of stored products and postharvest research. 2012; 3(9): $133-136$.

12. Ajala AS and A Gana Analysis of challenges facing rice processing in Nigeria. Journal of food processing. 2015; (6): 20-37 http://doi.org/10.1155/2015/893673 


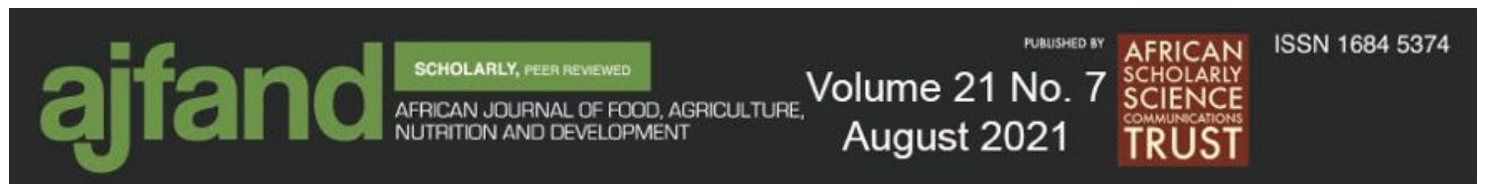

13. Ojogho $\mathbf{O}$ and GO Alufohai Comparative demand analysis for rice in Edo, Delta and Lagos states of Nigeria. Agrosciences journal. 2014; Article No 1 of Volume 12.1 .

14. Ayinde OE Evaluation of the effects of climate change on rice production in Niger state, Nigeria. Ethiopian Journal of Environmental Studies and Management. 2013; 6(6): 763-773.

15. Mishra A and V Salokhe The effects of planting pattern and water regime on root morphology, physiology and grain yield of rice. J Agron crop sci. 2010; 19(6): 368-378.

16. Emokaro CO and AA Ayantoyinbo Analysis of market integration and price variation in rice marketing in Osun state, Nigeria. American journal of experimental agriculture. 2014; 4(5): 601.

17. Egbedi OO, Okoruwa VO, Aminu A and $\mathbf{S}$ Yusuf Effect of rice trade policy on household welfare in Nigeria. European Journal of Business and Management. 2016; Vol 4, No.8.

18. Bennett D Record use of rice in recent years positive harbinger for 2014 crop. Delta Farm Press. 2014: 71(10): 14.

19. Ugochukwu AI and CI Ezedinma Intensification of rice production systems in South Eastern Nigeria: A policy analysis matrix approach. International Journal of Agricultural Management \& Development (IJAMAD). 2011; 1(2):89-100.

20. Matanmi BM, Adesiji GB, Owawusi WO and FO Oladipo Perceived factors limiting rice production in Patigi Local Government Area of Kwara State, Nigeria. Journal of Agriculture and Social Research (JASR) 2011; 11(2): 1-6.

21. Gumma MK, Nelson A, Thenkabail PS and AN Singh Mapping rice area of South Asia using MODIS multitemporal data. J Appl Remote Sens, 2011; 5:3.

22. Yoshida H, Nakagawa H, Ohno H, Nakazono K, Kondo M, Iwasawa N, Usui Y, Tokida T, Hasegawa T and T Kuwagata Factors that influenced the taste of Koshihikari rice produced in Hokuriku region in 2010. Jpn. J. Crop Sci. 2012; 81(1) : 128-129.

23. Washio K The Prediction of climate change and rice production in Japan. J Rice Res 2013; 2:103. https://doi.org/10.4172/jrr.1000e103

24. Bwala MA, Kokoye HSE and RN Yegbemey Technical efficiency of cereal production in north central Nigeria: a case for maize, rice and sorghum farmers. Journal of Agricultural Science and Environment. 2015; 15(1):25 34. 


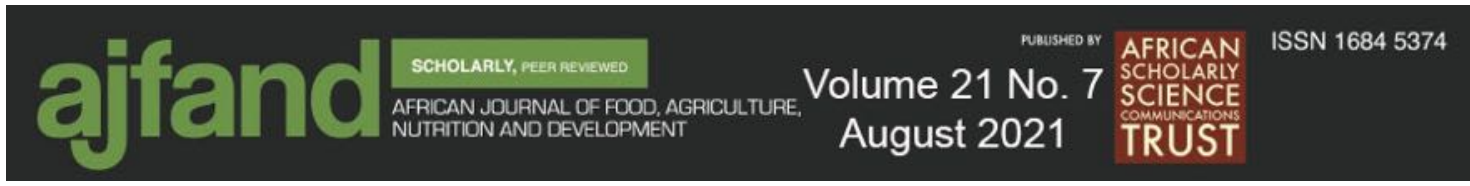

25. Abubakar HN, Kolo IN, Yabagi AA and Y Garba Adoption of production technologies by lowland rice farmers in Lavun local government areas of Niger state, Nigeria. Int J Agric Ext, 2016; 4: 49-56.

26. Kadiri F, Eze C, Orebiyi S and I Nwaiwu Determinants of sustainability of paddy rice production in Niger Delta region of Nigeria. Journal of Economics and Sustainable Development. 2014; 5: No.14.

27. Tanko M, Iddrisu A and AF Alidu Determinants of rice yield in Northern region of Ghana, the role of policy. Asian Journal of Agricultural Extension, Economics \& Sociology. 2016; 9(2): 1-11.

28. Omofonmwan SI and MA Kadiri Problems and prospects of rice production in central district of Edo State, Nigeria. Journal of Human Ecology. 2017; 22(2): 123-128. https://doi.org/10.1080/09709274.2007.11906010

29. Merem EC, Twumasi Y, Wesley J, Isokpehi P, Shenge M, Fageir S, Criler M, Romorno C, Hines A, Hirse G, Ochai S, Leggett S and E Nwagboso Analyzing rice production issues in the Niger state area of Nigeria's middle belt. Food and Public Health. 2017; 7(1): 7-22. https://doi.org/10.5923/j.fph.20170701.02

30. Okeke CG and SI Oluka A Survey of rice production and processing in Southeast Nigeria. Nigerian Journal of Technology (NIJOTECH). 2017; 36(1): 227-234 https://doi.org/10.4314/njt.v36i1.27

31. Campbell CJ Space, Place and Scale: Human Geography and Spatial History in Past and Present. Past \& Present, 2018; 239(1): 23-45

https://doi.org/10.1093/pastj/gtw006

32. Anyadike RNC “Climate and Vegetation” in Ofomata, G.E.K. (ed). A survey of Igbo Nation. Africana Publishers Ltd, Onitsha, pp 2002;73-82.

33. Igbozuluike MU "Vegetation" in Ofomata, G.E.K. (ed). Nigeria in Maps: EasternStates. Ethiope Publishing House, Benin City, pp 1974;30-31.

34. Federal Government of Nigeria. (2007): Federal Republic of Nigeria Official Gazzette 94(4) Government Printer Lagos.

35. Ofomata GEK “Relief” in Ofomata, G.E.K. (ed). Nigeria in Maps: Eastern states. Ethiope Publishing House, Benin City. 1975: pp 8-9.

36. Ofomata GEK "Relief, drainage and landforms" in Ofomata, G.E.K. (ed). A survey of Igbo Nation. Africana Publishers Ltd, Onitsha. 2002a: pp 83-98.

37. Ndebeh AK, Asumanah P, Ndebeh J, Ndaloma PG, Lahai SJB, Kolleh DM and JK Ahiakpa Agronomic performance of four upland rice genotypes under rainfed condition. Afr. J. Food Agric. Nutr. Dev. 2018; 18(2): 13304-13316 DOI: 10.18697/ajfand.82.16685. 


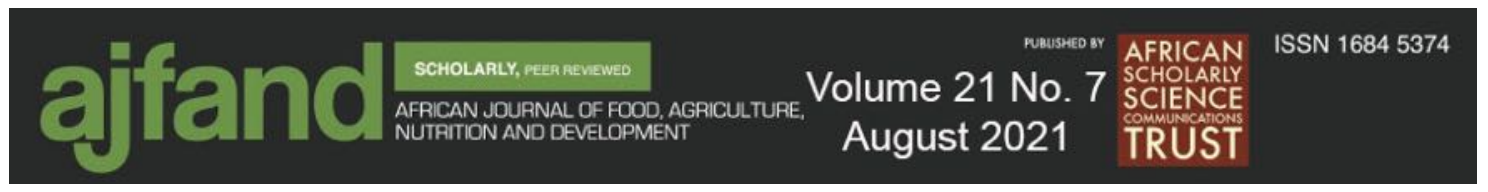

38. Oko AO, Ubi BE and AA Efisue A Comparative Study on Local and Newly Introduced Rice Varieties in Ebonyi State of Nigeria based on Selected Agronomic Characteristics. International Journal of Agriculture and Forestry 2012; 2(1): 1117. https://doi.org/10.5923/j.ijaf.20120201.03

39. Adenuga AH, Omotesho OA, Ojehomon VET, Diagne A, Ayinde OE and A Arouna Adoption of improved rice varieties and its impact on multi-dimensional poverty of rice farming households in Nigeria. Applied Tropical Agriculture. 2016; 21: No.1: 24-32. 